\title{
Employability Distress: Factors Affecting ICT Graduates’ Employability and Work Integration in the Workspace
}

\author{
Kenneth Nwanua Ohei ${ }^{1} \&$ Roelien Brink ${ }^{1}$ \\ ${ }^{1}$ Department of Applied Information Systems, School of Consumer Intelligence \& Information Systems, University of \\ Johannesburg, Bunting Campus, South Africa \\ Correspondence: Kenneth Nwanua Ohei, Department of Applied Information Systems, School of Consumer \\ Intelligence \& Information Systems, University of Johannesburg, Bunting Campus, South Africa.
}

Received: May 22, 2020

Accepted: July 13, 2020

Online Published: January 6, 2021

doi:10.5430/rwe.v12n1p138

URL: https://doi.org/10.5430/rwe.v12n1p138

\begin{abstract}
There has been an ongoing debate on the subject of graduate unemployability in South Africa and the extent to which it has affected academic graduates. The growing consensus regarding intensifying levels of graduate employability distress today is explicitly supported theoretically in a number of research studies. This is despite the considerable efforts that have historically been made concerning the graduate labour force and their probable ramifications in the context of South Africa's far-reaching labour market issues. A number of scholars both in the past and the present have identified several issues emerging from the heterogeneity of the quality of education, graduates' capabilities and skills competencies, higher education institutions' involvement in the industries and employers' requirements for employment. This study aimed to explore the views that graduates conceive about employability and stress, reason for their unemployment and identify the factor that causes them to be unemployed and decisively suggest way to address these challenges. A quantitative approach and a questionnaire were used. A total of 195 questionnaires from graduates/students in the College of Business and Economics were recovered and usable. The findings reveal a paradox in the increased level of ICT graduate unemployment and skills mismatch and shortages. This has been attributed mostly to organisational changes which may have given rise to misalignment between the skills that graduates currently have and those that employers seek from graduates. Findings suggest that the kind of education obtained, graduates' incapability to apply the skills received and work experience are factors hindering employability.
\end{abstract}

Keywords: graduates, Information and Communication Technology (ICT), employability skills, Higher Education Institution (HEI), skills mismatch, skills shortage and unemployment

\section{Introduction}

Graduate unemployment is often characterised as an economic crisis which poses complications for human self-worth (Van Broekhuizen, 2016; Cloete, 2015). Mokwena and Morojele (2014) are of the opinion that graduates' unemployability challenges are interrelated with other problems facing society. Cloete (2015) further states that the issue of employability remains the biggest theft of hope among graduates and young people in South Africa. This is in line with Du Plessis and Smith (2007), who affirm that graduate employability has decreased due to the increase in demand for highly skilled labour, which in turn suggests a decline in the demand for unskilled labour with the initiative to expand global competitive advantage.

According to Tripathy (2018), organizations are constantly and speedily expanding their business operations to different dimension. Gone are those eras when only graduates' ability and capabilities that were reckoned. Recently, organizations have discovered that the significant aspect of realising added and accomplishing success in the workspace is when graduates of various skills are teamed-up to work as collectives. This capability to function as collective in a team is regarded amongst the fundamental skill that a graduated ought to bring to the workspace. Thus, business organizations keening to employ graduates who can not only deliver their individual thoughts but again, who will be able to generate and mature projects and strategies jointly with capable graduates (Tripathy, 2018).

In South Africa, there is a dispute about whether graduate employability is a significant and growing problem (Rogan \& Reynolds, 2016; Mncayi \& Dunga, 2016; Kraak, 2010; Pauw, Oosthuizen \& Van der Westhuizen, 2008). The overall view remains that, in spite of a skills gap in the labour market, there is apparently a mismatch between the skills expected by employers/industries and the training offered by universities to information and communication 
technology (ICT) graduates. Notably, Rogan and Reynolds (2016) believe that the problem of graduate unemployment in South Africa has been over-exaggerated despite the many unresolved questions arising from the heterogeneity of the quality of education received, graduates' capabilities and skills competencies, the engagement of higher education institutions (HEIs) with industry and employers' criteria imposed on graduates for employment. The focal point of this paper is ICT graduates as they are the biggest cohort of new job seekers and possibly the most vulnerable group likely to be exposed to the struggle of employability in the industry (Ohei \& Brink, 2019).

Lee, Pitesa, Pillutla and Thau (2018), Saad and Majid (2014) argue that it appears that graduates with degrees in the hard sciences such as chemistry or even in, for instance, engineering, applied information systems (AIS), information technology management (ITM), ICT and computer science (CS) have the likelihood of obtaining employment based on physical attractiveness. Those graduates in the humanities or social sciences are more likely to encounter unemployment challenges or experience longer job searches (Mncayi \& Dunga, 2016; Spaull, 2013). This is not to say that the humanities do not hold a place in the labour market, but the accessibility of jobs outweighs the annual number of university graduates. Mncayi (2016) adds that not all graduates will enjoy better job openings mostly because of varied circumstances and job mismatches in the labour market.

In summary, graduates from the different disciplines, both skilled and unskilled, are not exempt from unemployment challenges in South Africa (Cloete, 2015). This paper probed the employability distress that graduates of ICT are encountering when seeking for employment in the labour market and coupled with challenging factors that limits their chances of employability. The rationale for this investigation, is for the fact that most ICT graduates are unable to secure employment when through with their respective qualification. As bad as it may seem, those who secured jobs, are perhaps not employed in their desired line of career profession. The investigation becomes relevant given the context of the occurrences surrounding the increasing rate of unemployment crisis in South African. Conceivably, graduate unemployment is one of the main prevalent problem facing South Africa today. The magnitude of this joblessness within the countries' economy can be well understood from the fact that the scale of unemployment rate is gradually increasing year after year and now the issue with COVID-19. Given the unprecedented outbreak that has gripped the country' economy, the issue of graduate unemployment will continue to rise globally, due to the problematic nature and impact of the COVID-19. Therefore, graduates' employability distress is not only problematic, however, it poses severe economic burden, wasteful scarce human capital, and societal consequences wherefore a graduate of a country is disengaged in the service of the country.

\subsection{Research Questions}

The following are the emerging research questions.

1) What are the views of ICT graduates concerning unemployment and employability stress?

2) Why do most ICT graduates struggle to secure employment?

3) What are the factors that affect ICT graduates' employability?

4) How can these issues of ICT graduate employability be addressed?

\section{Literature Context}

The need to prevent the undesirable effects of graduate unemployment has made unemployment issues to feature prominently in the development plans of many emerging countries (Hamilton, Carbone, Gonsalvez \& Jollands, 2015). The ability of ICT graduates to mature and become accustomed to repackaging their capabilities is a fundamental aspect in employability (Ohei \& Brink, 2019). Academic literature was reviewed to offer meaningful insight and understanding of employable skills required in the workspace. This uncovered the factors contributing to ICT graduate unemployment and challenges confronted with when seeking employment workspace. This section starts with a brief discussion HEI context and followed the nature of graduate unemployment rate in the country.

HEIs are considered a crucial asset supporting, promoting and enabling graduates/students to mature their employability skills and preparing them for desirable skilled occupation (Abel \& Deitz, 2016). Traditionally, those who have invested in pursuing a career qualification ought to benefit substantially from economic aspects and continue to benefit from them over their lifetime. Moreover, with the advent of the pronounced recession and the inactive labour market that has resulted, there have been reports of university graduates struggling to secure jobs in their chosen profession (Ohei \& Brink, 2019). Those who are able to secure employment are often limited to low-wage positions. This poses disturbing questions about whether a university qualification degree still offers avenues for graduates to find well-paying jobs (Ohei, Brink, Abiodun, 2019; Abel \& Deitz, 2016).

Research evidenced (Ohei et al., 2019, Ohei \& Brink, 2019; Van Broekhuizen, 2016) has progressively highlighted 
that the relative labour market interests of HEIs in South Africa may largely be deteriorating. The decrease in graduate labour market productivity in South Africa is time and again attributed to a combination of the HEIs' lack of responsiveness to structural changes in the domestic economy since 1994. In an analysis of the South African discourse on joblessness among people with the highest level of educational qualifications, Kraak (2010) contends that this skills mismatch has intensified South Africa's prevailing skills shortage and adversely affected graduate employability and subsequent labour market prospects of graduate individuals to a larger extent (Saad \& Majid, 2014).

\subsection{The Nature of the Graduate Unemployment Rate in SA}

Unemployment is a situation in which a graduate or an individual is optimistic, willing and has a positive attitude to work but cannot find a job (Ohei \& Brink, 2019; Baldry, 2016), yet such an individual may have gone to university or perhaps obtained relevant training to enable that individual become employable. The Quarterly Labour Force Survey of Statistics SA is often regarded as a household-based survey. Stats SA (2018) revealed that as at 2013, unemployment was at $25.5 \%$. Thereafter, the general unemployment rate increased by $1.2 \%$, bringing the rate to $26.7 \%$ in the first quarter of 2017, which was about 6.2 million people who were unemployed (Taljaard \& Van der Walt, 2018).

The South African working-age population increased by 153000 or $0.4 \%$ in the first quarter of 2018 compared to the fourth quarter of 2017. The unemployment rate at $26.7 \%$ persisted in the first quarter of 2018 compared to the fourth quarter of 2017 (Stats SA, 2018), and the cause for concern is that currently the unemployment rate in SA is 29\% (Stats SA, 2019).

While high unemployment among graduates has gained significant attention from decision makers and society as well, there are rising concerns that new graduates are finding themselves underemployed. Unemployable graduates have resulted in university graduates becoming underemployed, i.e. working in jobs that do not require a university qualification, for example as bartenders or retail clerks. In this instance, a university graduate is described as a student with at least a bachelor's degree, approximately between 22 and 27 years of age (Abel \& Deitz, 2016).

The recent joblessness and unemployability of graduates signify a bizarre and huge waste of resources and an increasing level of anguish among graduates. This has led to rising social segregation, intensifying disparity among and within nations and a host of societal problems (Livingstone, 2018). This is consequently both ethically intolerable and economically irrational. Brink (2014) maintains that HEIs are under an immense burden to enhance their graduates for industry. This can be achieved by incorporating the component of work integration learning/work-integrated learning (WIL) to adhere to criteria set out by employers. Research evidence suggests that students would benefit massively as a result of WIL in their academic studies, as this will increase their learning abilities, improve problem-solving skills and serve as motivation for learning.

\subsection{Work Integration Learning (WIL)}

In this paper, the terms "work integration learning" or "work-integrated learning" are used interchangeably. WIL is broadly referred to as an instrument used to prepare young graduates with the relevant and desired employability abilities both in hard and soft skills, allowing the graduates to function proficiently in the work environment. The essence of WIL is nothing but improving skills development. It entails the process of what, how and from whom students acquire essential skills during work placement (Jackson, 2015).

Brink (2014) and Ohei and Brink (2019) explains that WIL is a programme that is precisely directed at students where learning in the classroom alternates with learning in the labour force and that allows room for the competencies, proficiencies and capabilities of students to be built, nurtured and developed by educators (Brink, 2014). WIL proposes better opportunities for students to absorb extensive knowledge and be sure of support from different role players at the university and in industry. The processes of WIL work hand-in-hand with information management (IM) theory, where each individual involved has a dynamic and fundamental role to play effectually and appropriately in the exact situation.

Brauns (2013) emphasises that graduates lack the central skills and knowledge needed in the workforce, and industry is seeking graduates who possess all the relevant skills to do the job required, as well as the ability to combine those skills proficiently in the workplace. Cooper, Orrell and Bowden (2010) maintain that the distribution of knowledge, experience, concepts and contents form the basis for an ideal WIL process. This process is explained in the WIL procedural model of Brink (2014). 


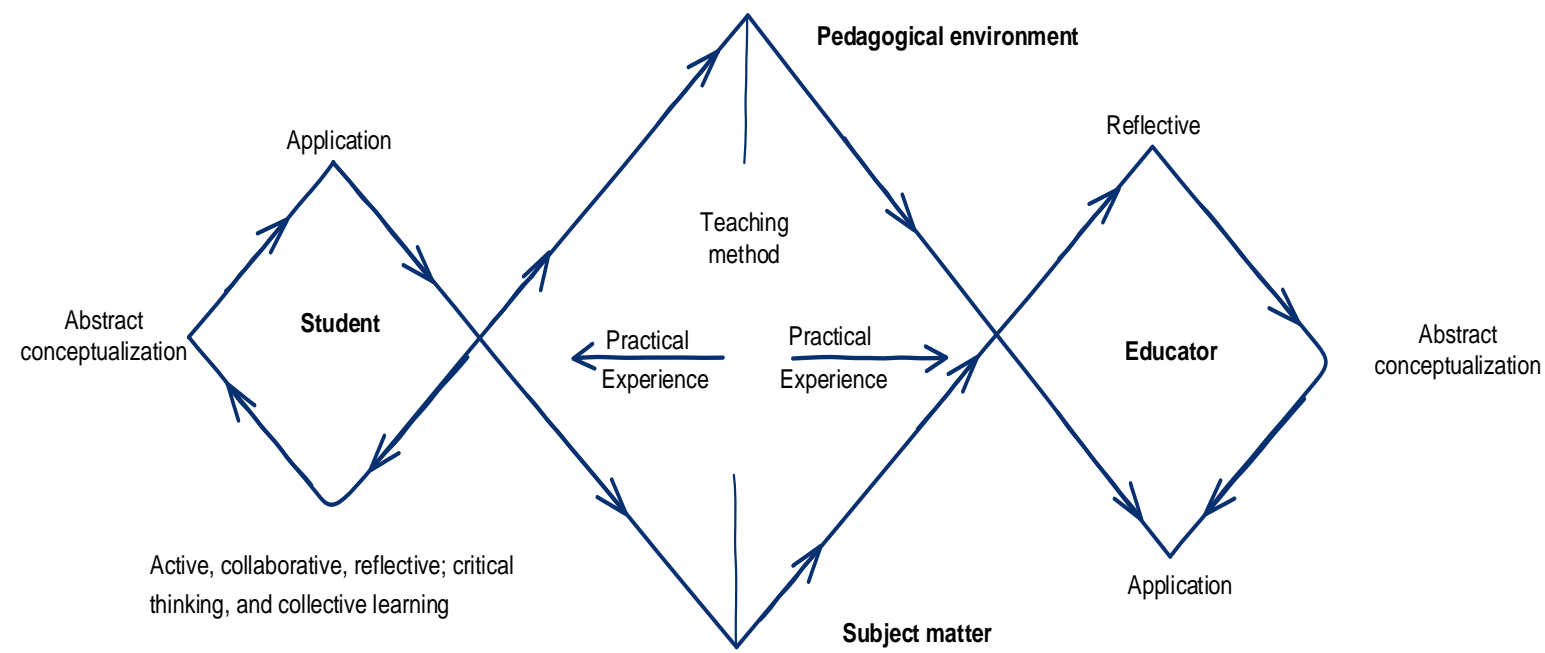

Figure 1. Procedural approach to WIL (Brink, 2014)

\subsection{Graduates' Perceptions of Employment, Unemployment and Their Effects}

South African graduates in society refer to or rather perceive employment as the most crucial aspect of human existence. Questions such as: what you would like to become one day or what kind of work would you like to be employed in, indicate that at some point in life, graduate employability is essential to social status and lifestyle (Cloete, 2015 \& Saad \& Majid, 2014).

According to some theorists, an individual's worth is classified or categorised through their earning from being employed (Cloete, 2015; Claassens, 2011). Employment serves countless collective and interpersonal purposes and allows individuals the prospect of satisfying their psychological desires. These theorists maintain that employment offers social security, restoration of dignity, recognition and much more. A job can produce a sense of value and worth and form a person's personality and self-esteem. So many South African graduates really want to work as it would offer greater opportunities. However, not many graduates are employable. The issue of unemployment has prevented most graduates from entering the South African labour force.

Unemployment in South Africa is perceived by graduates as placing their psychological or mental well-being in jeopardy. Most unemployed individuals show a continuous decrease in satisfaction with life, mental health and self-assurance, and signs of sadness and depression. Most of these individuals have been unemployed for a long period. In addition, unemployment is sometimes the root cause of social problems such as crime (Ohei \& Brink, 2019 \& Cloete, 2015).

This highlights the negative psychological implications of a graduate who has remained unemployed, which include nervousness, low self-esteem, cynicism, despair, increased alcoholism, laziness, suicide and other stress-induced illnesses such as pains, stomach ulcers, heart diseases and many more (Cloete, 2015).

\subsection{Graduates' Employability Skills Needed in the Industries}

Lowden, Hall, Elliot and Lewin (2011) and Ohei and Brink (2019) define employability as a set of qualities, skills, knowledge and experience that a person who wishes to participate in the labour market should possess to guarantee that the person has the competence to be productive in the workplace. This will benefit not only them, but also their employer and the broader economy. Ohei et al. (2019) define employability as a set of talents, experiences, thoughtfulness and personal characteristics that distinguish an individual, or make that individual more likely to choose and secure jobs in which they can be fulfilled and successful (Ohei \& Brink, 2019).

For companies, finding the right candidate or graduate to take up employment simply implies recognising a specific person who has the right skills and quality traits and is capable of fulfilling the duties and ultimately adding value to the organisation's growth (Ohei et al., 2019; Ohei \& Brink, 2019; Rosenberg, Heimler \& Morote, 2012). Graduates may have the desired educational qualifications and hard skills to be capable of fulfilling the job description, but without a combination of soft skills as well as other related quality traits, employers are more likely to be less motivated to 
employ them.

The notion that graduates are expected to absorb and possess certain general qualities and possible academic traits absorbed through their educational learning process and experiences has been widely debated (Ohei \& Brink, 2019). While a graduate's education through teaching, learning and experience is pivotal in making them more eligible to apply for a job, to be part of the labour market, graduates may be required to have a combination of skills, referred to as employability skills.

Thus, in order for graduates to gain access to the labour market, they should acquire certain employability skills such as self-confidence and independence, as well as professional skills. Ohei et al. (2019), Ohei and brink (2019) and Saad and Majid (2014) suggest that graduates need to be well prepared and are expected to have certain generic or self-attributed qualities. Further points out a misalignment between theory and application through practical work in almost all programmes at universities. University courses have been based primarily on theory and have overlooked the technical to prepare their students for the workplace. Several studies, such as those by Ohei et al. (2019), Ohei and Brink (2019), McKenzie, Coldwell-Neilson and Palmer (2017), Mncayi (2016) and Griesel and Parker (2009), contend that there might be a misalignment between unrealistic requirements of companies and what graduates actually bring to the workspace. Meanwhile, graduates often have high expectations that their first employment will be a highly paid and desirable position in line with their profession, only to discover that many entry-level jobs do not even come close to what they have anticipated or expected (Ohei \& Brink, 2019).

\subsubsection{Intellectual Ability and Competence}

Among the skills that a graduate is required to have are sound intellectual capability and experience to meet the workplace demands and fulfil opportunities. This includes the ability to define assumptions, build a reasonable argument, engage in simple enquiry, apply research skills, be interested and have a desire to improve (McKenzie et al., 2017; Saad \& Majid, 2014; Griesel \& Parker, 2009). Regrettably, it is apparent that many graduates do not possess these skills. There is a gap between employers' unrealistic criteria and expectations and the quality of graduates' traits. This leads to the argument concerning the disparity between the kind of education received from universities and the employers' criteria or standards for employability.

Workplace skills are also regarded as fundamental, since graduates must move away from the state of being theoretically inclined to the practical aspects of employment. This type of skill allows the transition from theory based to practicality, giving graduates the ability to cultivate a widespread approach to problem-solving, the capability to plan, initiate and execute tasks self-sufficiently and many more. Griesel and Parker (2009) and Saad and Majid (2014) emphasise that the requirements of employers are not fully adhered to, which justifies the reasons for graduates not being employable or unable to secure employment.

\subsubsection{Hard and Soft Skills}

In terms of hard and soft skills, these are transferable skills or central competencies (Bridgstock, 2009). Ohei and Brink (2019), for instance, soft skills entail reliability, intellectual ability, collaboration and teamwork skills, logic and problem-solving skills, generic communication skills and an appreciation for the workplace so that the graduate can function proficiently. Other related quality traits and basic skills are computer knowledge, verbal demonstration skills, practical capability, expertise in the academic field of study and the ability to find and access information (Ohei et al., 2019 \& Brink, 2019), which are important aspects of a graduate's basic skills and understanding (Pramudia, Ardiwinata, Sudiapermana \& Hilmi, 2019; Griesel \& Parker, 2009).

\subsection{Factors Contributing to Employability Distress}

Mismatches can be classified into two groups: skills mismatches and qualification mismatches. Ohei \& Brink (2019) reveals that a skills mismatch occurs when the higher education system is ineffective in producing the quality of graduates who have the skills needed in the country and supported by (Graham, Williams \& Chisoro, 2019). A skill mismatch also occurs when an employee has a higher or lower skill level than expected to function adequately in their job (Farooq, 2011). A qualification mismatch arises when the qualifications that a graduate has are either higher or lower than those expected by employers.

A career pathway is also an attribute that needs to be considered in the context of skills mismatches. It is repeatedly supposed that a career pathway in the areas of engineering, CS, ICT, AIS and ITM means that graduates definitely have the employability skills required by employers. This suggests that a qualification obtained in any of these career paths or any other ICT-related field influences graduates' opportunities of securing a desirable job that is best in line with their profession (Ohei \& Brink, 2019). This is why the quality of a graduate is often reliant on the level of education that the HEI has to offer (Rogan \& Reynolds, 2016). 
Bhorat, Mayet and Visser (2012) reveal that graduates who attended a historically underprivileged institution stand less chances of getting into the labour market compared to those who attended privileged institutions (Ohei \& Brin, 2019). HEIs have a key role to play in ensuring that graduates become employable. When graduates search for jobs, they are unable to acquire details about job availability or job requirements or they are inexperienced in job application procedures. This often has a major impact on a graduate's employment profile.

Most importantly, skills such as verbal, communicating, writing and computer skills are highly recommended and are deemed paramount for a successful job search and application process (Hamilton et al., 2015). Employers indirectly or directly have either a positive or negative perception about the quality of graduates, which in turn is reflective of the university from which the qualification was attained (Ohei \& Brink, 2019).

Research shows that unrealistic criteria by employers, unrealistic expectations, employers' perceptions based on previous experience (i.e. employing unskilled graduates), work experience, graduates' job search approach, quality of graduate and HEIs' education delivery approaches are all associated with preventing graduates from being employable (Saad \& Majid, 2014).

\section{Methodology}

In the South African context, graduate unemployment is one of the main prevalent problem facing the country today. The effect of the unemployability of graduates within the countries' economy can be well understood from the fact that the scale of unemployment rate continues to give rise year after year and now the issue with COVID-19. The unprecedented outbreak that has gripped the country's economy, hence the issue of graduate unemployment will continue to upsurge globally, due to the impact of the COVID-19. Thus, graduates' employability distress is not only problematic in nature, conversely, it poses severe economic strain and societal consequences wherefore a graduate of a country is detached in the service of the country.

According to Creswell (2014), the philosophical assumptions, design and methods are crucial to the purpose of any research endeavour. This paper was keyed in the quantitative research investigation which warranted the use of questionnaire technique for data gathering approach. This approach chosen was deem fit as it offers a better platform to collect a substantiable amount of dataset for the project. The questionnaire was tested before the initial distribution of the questionnaire and the necessary adjustments were perfected. The questionnaire was designed and sent to a qualified statistician, who ensured that it remained compliance with ethics and the respondents would not find it difficult when filling the questionnaire. A covering letter clarified the purpose of the study, the length of the questionnaire, as well as researchers' details and how the results would be used. The questionnaire targeted 250 was randomly selected from the universities database and $\mathrm{N}=195$ of $78 \%$ responses rate were recovered and usable. The information that were gathered was then captured using Microsoft Excel sheet, and later transferred to the SPSS Statistics Version 23 and the information was coded and labelled to represent meaningful information for interpretation and analyses. The data was analysed using figures and tables for the representation and readership.

In order to comply with ethical scholastic research morals, consent was acquired through all the relevant ethical procedures. It was then that voluntary involvement, privacy and confidentiality were guaranteed throughout the study. The respondents were male and female graduates/students of the College of Business and Economics (CBE) who had completed their higher education degree at the University of Johannesburg, across the four campuses. The study aimed to examine the reasons behind ICT graduates' employability distress, its effect on graduates and their employability skills. The rationale behind focusing on CBE graduates was the general assumption that a university degree in any of the qualifications in AIS, ITM, ICT and CS would result in better job opportunities that were highly paid (Mlatsheni, 2012; National Treasury, 2011; Stats SA, 2018). These graduates may have invested substantial resources in higher education in pursuit of the aforementioned qualifications with the hope of a high return.

\section{Results, Discussion and Findings}

The findings based on the research questions are now discussed. The first step was to answer the question of how graduates perceived unemployment challenges that they faced on a daily basis. The second was to identify the reasons why most ICT graduates are unable to secure their ideal job opportunity that was in line with their professional qualifications. The next steps were to understand what skill sets graduates believe employers expect ICT graduates to acquire, what factors cause graduates to become unemployable and how these issues of employability can be handled appropriately. The analyses of the demographic variables of gender, career discipline, institution and age category of the respondents are dealt with first. 


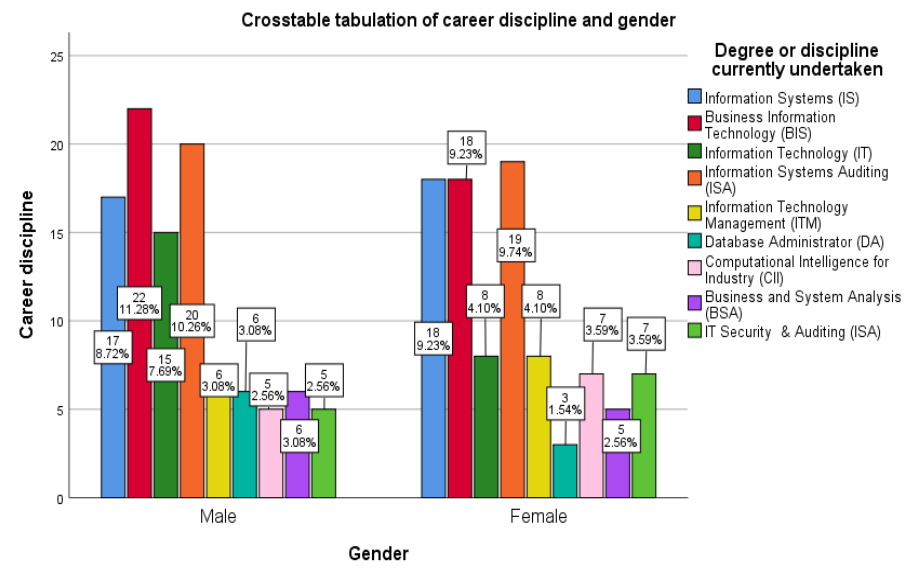

Figure 2. Respondents' career discipline and gender

Of the 195 respondents, there were more males in business information technology and information systems auditing at $11.28 \%$ and $10.26 \%$, respectively, compared to females at $9.23 \%$ and $9.74 \%$, respectively. There were more females in information systems (9.23\%), information technology management (4.10\%), IT security and Auditing (3.59\%) and computational intelligence for industry (3.59\%) compared to males.

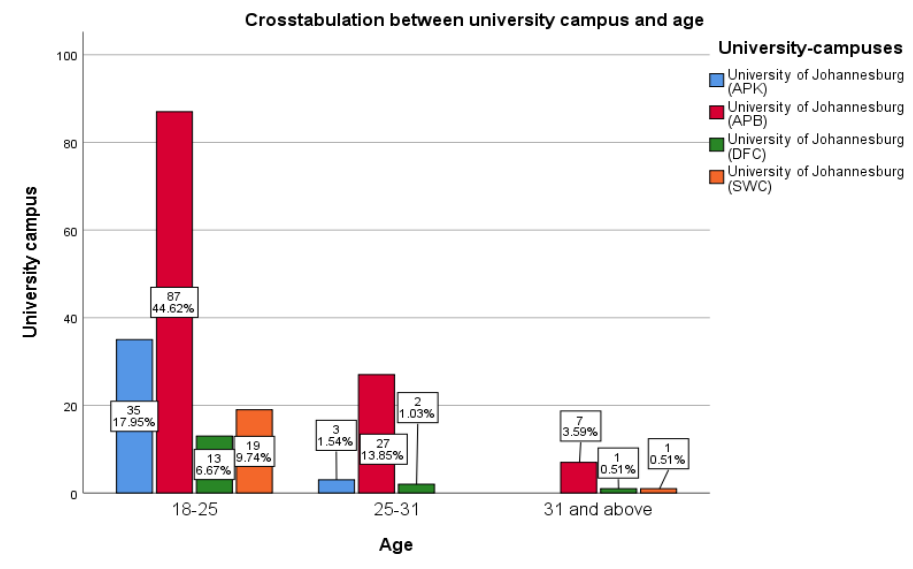

Figure 3. University and age category

As shown in Figure 3, this study targeted the University of Johannesburg, across four campuses. The majority of the respondents fell within the age category of 18-25, followed by 25-31. The age category of 31 and above was insignificant.

The findings imply that in the educational environment, a student who falls in the age category of $18-25$ is assumed to have completed and obtained their first-degree qualification, given that most academic course programmes take 3-4 years to complete. A statistical analysis was conducted of the period 2000 to 2019, which indicates when ICT graduates surveyed completed their degree or qualifications. The findings show that the years 2016 and 2017 were significantly represented compared with the remaining years in which ICT graduates obtained their qualifications within their respective academic disciplines. This indicates that graduates had been actively searching for employment and were available for any possible opportunities. $28.7 \%$ and $27.2 \%$ of graduates had been available for employment for 6 months to 1 year and for more than 1 year, respectively.

This paper focused on the employability distress of ICT graduates/students and attempted to offer viable insight into how ICT graduates/students perceive the challenges of unemployment. As discussed earlier, several academic sources 
reveal that the employability issue remains the biggest theft of hope among graduates/students and young people in South Africa. Therefore, the study sought to understand how graduates perceive unemployment and employability challenges and to determine the factors behind graduate unemployment, what employers require and the skills they expect from graduates and how graduates can fulfil these requirements and expectations.

\subsection{Graduates' Views of Employability}

ICT graduates/students worry about whether they will be able to secure the right employment in the labour force after completing their degree. This section of the questionnaire attempted to determine how ICT graduates felt about employability and unemployment and the effect of this stress on graduates. The challenges that come with unemployment have to some extent restricted most ICT graduates/students from entering the South African labour market. Questions in this section of the questionnaire were about the ICT graduates' employability status, application process and job search aptitude, whether they received feedback from employers on job applications, what platforms were being utilised for job applications and whether they would continue to search for possible job opportunities. All these questions were asked in order to fully understand graduates' views of employability.

Table 1. Current employability status of graduates

\begin{tabular}{lll}
\hline Itemised & Frequency & Per cent \\
\hline Employed & 51 & $26.2 \%$ \\
\hline Unemployed & 144 & $73.8 \%$ \\
\hline Total & $\mathrm{N}=195$ & 100.0 \\
\hline
\end{tabular}

Table 2. Job held in line with academic qualification or profession

\begin{tabular}{lll}
\hline Itemised & Frequency & Percent \\
\hline Yes & 30 & $15.4 \%$ \\
\hline No & 68 & $34.9 \%$ \\
\hline N/A (Unemployed) & 97 & $49.7 \%$ \\
\hline Total & $\mathrm{N}=195$ & 100.0 \\
\hline
\end{tabular}

Table 1 presents the responses gathered from the ICT graduates in relation to their employability status. The results show that employability is a major concern for most ICT graduates/students. Of the 195 ICT graduate/student respondents, the majority (144 or $73.8 \%$ ) remained unemployed. This gives rise to the question whether a university qualification still offers avenues for ICT graduate employability and opportunities in well-paying jobs (Abel \& Deitz, 2016).

While high unemployment among ICT graduates remains the centre of attention and has gained substantial consideration from decision makers and society as a whole, there is also an increasing concern that many ICT graduates are finding themselves underemployed.

A follow-up question was asked to determine the state of their job positions. 15.4\% agreed that the job positions that they were employed in were in line with or related to their academic qualifications; $34.9 \%$ believed that their job positions were not in line with their academic profession or qualifications. The majority of respondents (49.7\%) were unemployed.

This shows that ICT graduates/students who are unable to find employment that fits into their academic line of profession or that speaks directly to their academic qualifications take up job employment as clerks, retailers and receptionists. This is often referred to as underemployment or limited low wage earning.

Joblessness and underemployment of ICT graduates suggest a bizarre and huge waste of capital and resources and an increased level of anguish among graduates. This may give rise to social segregation, intensifying disparity among graduates and a range of societal problems (Ohei \& Brink, 2019; Livingstone, 2018).

Table 1 reveals the statistics of ICT graduates' employability status, but it was also fundamental to ascertain whether ICT graduates were motivated to secure job opportunities by applying and hunting for jobs, irrespective of their 
employability challenges. In so doing the study sought to understand their commitment to the job search and application process.

Table 3. Job searches undertaken if unemployed

\begin{tabular}{lll}
\hline Itemised & Frequency & Per cent \\
\hline Yes & 130 & $66.7 \%$ \\
\hline No & 65 & $33.3 \%$ \\
\hline Total & $\mathrm{N}=195$ & 100.0 \\
\hline
\end{tabular}

Table 4. Desired action if unemployed

\begin{tabular}{lll}
\hline Itemised & Frequency & Percent \\
\hline Find a job & 88 & $45.1 \%$ \\
\hline Start business & 61 & $31.3 \%$ \\
\hline Continue studying & 19 & $9.7 \%$ \\
\hline All of the above & 27 & $13.8 \%$ \\
\hline Total & $\mathrm{N}=195$ & 100.0 \\
\hline
\end{tabular}

The table 3 above suggests that the majority of the ICT graduates had been seeking employment opportunities. Some graduates were optimistic that they would continue to search and apply for any possible job opening in the labour market. Others believed that starting their own businesses would be ideal, since it was a struggle to secure employment. Very few would opt to continue with their studies and possibly find a job or start up a business.

In their job search approach, not many ICT graduates were able to obtain details about certain job requirements and availability, and their inexperience with job application procedures often had a major impact on their employment profile. Graduates were asked to indicate the platforms used in their job application processes and searches.

Table 5. Tools or platforms used in job search

\begin{tabular}{llll}
\hline Itemised & Frequency & Per cent & V. per cent \\
\hline Employer websites & 20 & $10.3 \%$ & $10.3 \%$ \\
\hline University career portal & 21 & $10.8 \%$ & $10.8 \%$ \\
\hline Employer brochures & 17 & $8.7 \%$ & $8.7 \%$ \\
\hline National newspapers & 34 & $17.4 \%$ & $17.4 \%$ \\
\hline Internal application submission & 32 & $16.4 \%$ & $16.4 \%$ \\
\hline Commercial career websites & 26 & $13.3 \%$ & $13.3 \%$ \\
\hline Networking sites & 31 & $15.9 \%$ & $15.9 \%$ \\
\hline Career service directory & 14 & $7.2 \%$ & $7.2 \%$ \\
\hline Total & $\mathrm{N}=195$ & 100.0 & 100.0 \\
\hline
\end{tabular}

Table 5 lists the platforms used by ICT graduates to seek employment. The majority of the respondents used national newspapers, followed by internet application submissions, networking sites and employers' commercial career web pages or websites to gain insight into the employers' requirements for a specific job advert.

When graduates apply for job employment, it would be preferable for them to receive feedback on whether their application was successful or not. This would serve as motivation and encouragement for graduates to fully comprehend the areas that need improvement in their application approach. Unfortunately, employers never provide 
this feedback whether their application was successful or not or the area that need improvement. Despite their yearning to secure employment, a greater proportion of the respondents showed some hesitancy in applying or looking for lucrative employment, particularly where no feedback is given, or they are invited for an interview but only a few make it to the final conclusive interview.

Table 6 shows that $118(60.5 \%)$ of the respondents never received feedback on their applications. Table 7 shows that the majority (slightly more than half, 102 vs 92 who were invited for one or more interviews) were never invited for an interview.

Table 6. Positive or negative feedback received from employer

\begin{tabular}{lll}
\hline Itemised & Frequency & Per cent \\
\hline Yes (Successful) & 21 & $10.8 \%$ \\
\hline Yes (Unsuccessful) & 45 & $23.1 \%$ \\
\hline No feedback & 118 & $60.5 \%$ \\
\hline N/A (Employed) & 11 & $5.6 \%$ \\
\hline Total & $\mathrm{N}=195$ & 100.0 \\
\hline
\end{tabular}

Table 7. Number of interviews granted

\begin{tabular}{lll}
\hline Itemised & Frequency & Percent \\
\hline $1-2$ interviews & 75 & $38.5 \%$ \\
\hline 3-4 interviews & 10 & $5.1 \%$ \\
\hline More than 5 interviews & 8 & $4.1 \%$ \\
\hline Never invited for an interview & 102 & $52.3 \%$ \\
\hline Total & $\mathrm{N}=195$ & 100.0 \\
\hline
\end{tabular}

\subsection{The Effects of Unemployment on Graduates}

There is a psychological side to graduate unemployment which is viewed as crucial in this analysis as it aids an understanding of how graduates experience and respond to unemployment as human beings. In most cases, the economic effect of ICT graduate unemployment is well documented while the psychological effect is often sidelined. It is, however, of the utmost importance to understand the psychological effect of unemployment on graduates, as being unemployed impacts negatively on their well-being. Unemployment puts the mental health of graduates at risk as most unemployed graduates show a constant decrease in overall satisfaction with life, general well-being and self-esteem, and symptoms of depression, especially if they are unemployed for a long period. The evidence gathered from this study is reflected in Table 8, which supports this claim. The consequences of unemployment have been discussed extensively in the literature (Cloete, 2015).

Research studies suggest how unemployment could have a positive or negative impact on graduates as it denies them the sense of belonging or freedom or access to basic things in life. The analysis and discussion below provide a clearer justification of the negative effect of unemployment on ICT graduates (Rogan \& Reynolds, 2016; Mncayi \& Dunga, 2016; Kraak, 2010; Pauw, Oosthuizen \& Van der Westhuizen, 2008)

Table 8. Negative effect of unemployment on ICT graduates/students

\begin{tabular}{lllll}
\hline Itemised & C. agree & Agree & C. disagree & Disagree \\
\hline Causes low self-esteem & $30.8 \%$ & $37.9 \%$ & $14.9 \%$ & $16.4 \%$ \\
\hline Causes low self-confidence & $24.6 \%$ & $39.0 \%$ & $23.1 \%$ & $13.3 \%$ \\
\hline Lack of sense of belonging & $12.3 \%$ & $45.6 \%$ & $31.3 \%$ & $10.8 \%$ \\
\hline
\end{tabular}




\begin{tabular}{lllll}
\hline Lack of integrity and dignity & $25.6 \%$ & $33.8 \%$ & $22.6 \%$ & $17.9 \%$ \\
\hline Causes discouragement and demotivation & $32.3 \%$ & $35.4 \%$ & $20.5 \%$ & $11.8 \%$ \\
\hline Leads to crime & $29.7 \%$ & $33.8 \%$ & $21.0 \%$ & $15.4 \%$ \\
\hline Causes anxiety & $31.8 \%$ & $42.1 \%$ & $25.6 \%$ & $0.5 \%$ \\
\hline
\end{tabular}

Employment can result in social security and a sense of value and worth, and form a person's personality and self-esteem. As a result, many theorists suggest that an individual's worth is classified or categorised through their earnings from being employed (Claassens, 2011). Therefore, employment in this context allows individuals the prospect of satisfying their psychological desires. Graduates surveyed indicated that unemployment may lead to a lack of sense of belonging and it also causes anxiety, low self-confidence and low self-esteem. As a consequence of being unemployed, graduates are discouraged and demotivated, meaning that the zeal to keep searching for employment fades gradually.

\subsection{ICT Graduates' Inability to Secure Job}

With the current unstable economic crisis and issues surrounding the labour market as alluded to in the literature, the unemployment rate in SA has increased by $1.2 \%$ in the past few years, bringing the rate to $26.7 \%$ which is about 6.2 million people who are unemployed (Ohei \& Brink, 2019a; 2019b; Stats SA, 2018). The burning questions of where, what, when and why regarding ICT graduates' worries are denoted by $\left(4_{\text {ws }}\right)$ concerning job employment. "Where" signifies the industry/employer; "what" signifies the kind of employment available; "when" signifies the length of being unemployable upon graduation and finally "why" denotes the reasons why ICT graduates are not securing their desired job or are not employable (Ohei \& Brink, 2019b).

Table 9. Type of unemployment

\begin{tabular}{lll}
\hline Itemised & Frequency & Per cent \\
\hline I struggled to find a job & 78 & $40 \%$ \\
\hline Internship terminated/ended & 20 & $10.3 \%$ \\
\hline I voluntarily stopped working & 6 & $3.1 \%$ \\
\hline I have never worked before & 71 & $36.4 \%$ \\
\hline N/A (Employed) & 20 & $10.3 \%$ \\
\hline Total & $\mathrm{N}=195$ & 100.0 \\
\hline
\end{tabular}

\subsection{Factors Preventing ICT Graduates From Being Employed}

In order to ascertain the graduates' and students' collective responses and gain clarity regarding the data analysis, the responses "completely agree" and "agree" were merged to represent agree or affirmative, and the responses "disagree" and "completely disagree" were merged to represent disagree or negative. This analysis answered the third main research question in relation to issues preventing graduates from being employed.

\subsubsection{Chi-Square Test Analyses}

ICT graduates were asked to indicate whether they agreed or disagreed that the itemised factors served as a hindrance or prevented graduates from securing employment. The chi-square test of null hypothesis and alternative hypothesis was used to decide the degree of freedom between the independent variables. At a significance level of 0.05 where the p-value was less than or equal to 0.05 , the null hypothesis was rejected, and the alternate hypothesis was accepted. Where the p-value was greater than 0.05 , the null hypothesis was accepted. The factors listed were skills mismatch, skills shortage, type of education received, ICT graduates' inability to demonstrate the knowledge acquired through formal education, no work experience upon graduation and quality of graduate (Ohei \& Brink, 2019). 
Table 10. Skills mismatch as a factor affecting employability *Gender

\begin{tabular}{lllll}
\hline Itemised & & Male & Female & Total \\
\hline Skills mismatch & Completely agree & 36 & 32 & 68 \\
\cline { 2 - 5 } & Agree & 30 & 42 & 72 \\
\cline { 2 - 5 } & Completely disagree & 18 & 10 & 28 \\
\cline { 2 - 5 } & Disagree & 18 & 9 & 27 \\
\hline Total & & 102 & 93 & $\mathrm{~N}=195$ \\
\hline & p-value $=.620$ & Chi-square statistic $=\mathbf{7 . 1 6 6}$ & $\mathbf{d f}=\mathbf{9}$ \\
\hline
\end{tabular}

In an exploration of the discourse on joblessness and employability challenges among graduates and students, Kraak (2010) maintains that skills mismatch has intensified South Africa's prevailing skills shortages and has negatively affected graduate employability and labour market prospects more than any other scholastic cohort.

The underlying driver of ICT graduate unemployability is the economic crisis. Higher education is claimed to have contributed to a high proportion of graduate unemployment due to an oversupply of skilled labour that is not met by an increase in demand. Additionally, a repeated contributing factor to graduate unemployment, as mentioned earlier, is a general skills mismatch between the higher education system and the economy (Graham et al., 2019). The contention is that the education system does not satisfactorily produce graduates for future jobs and market demands and that industries are hesitant to employ graduates without having to incur the costs in upskilling them. In this section of the analysis, the tables below provide evidence of the extent to which respondents agreed or disagreed with the itemised variables identified as factors preventing ICT graduate from being employed (Saad \& Majid, 2014).

$H_{0}$ : Skills mismatch is a contributing factor that prevents ICT graduates from being employed (null hypothesis).

$H_{l}$ : Skills mismatch is not a factor preventing ICT graduates from being employed (alternate hypothesis).

The value of $\mathrm{X}^{2}$ is 7.166 on probability, with the df at 9 and a p-value of 0.620 , which is greater than the conventional significance level of 0.05 set to either accept or reject the hypothesis. Since p $>0.05$, the null hypothesis is accepted.

$H_{0}$ : The null hypothesis that skills mismatch is a contributing factor that prevents ICT graduates from being employed is accepted.

Table 11. Skills shortage as a factor preventing employment * Gender

\begin{tabular}{lllll}
\hline Itemised & & Male & Female & Total \\
\hline \multirow{2}{*}{ Skills shortage } & Completely agree & 44 & 24 & 68 \\
\cline { 2 - 5 } & Agree & 32 & 35 & 67 \\
\cline { 2 - 5 } & Completely disagree & 14 & 13 & 27 \\
\cline { 2 - 5 } & Disagree & 12 & 21 & 33 \\
\hline Total & p-value $=.068$ & 102 & 93 & $\mathrm{~N}=195$ \\
\hline & & Chi-square statistic $=\mathbf{1 7 . 0 4 4}$ & $\mathbf{d f}=\mathbf{9}$ \\
\hline
\end{tabular}

Table 12. Type of education received as a factor preventing employment * Gender

\begin{tabular}{|c|c|c|c|c|}
\hline \multicolumn{2}{|l|}{ Itemised } & Male & Female & Total \\
\hline \multirow{4}{*}{$\begin{array}{l}\text { Type of education } \\
\text { received as a factor } \\
\text { affecting employability }\end{array}$} & Completely agree & 34 & 29 & 63 \\
\hline & Agree & 38 & 34 & 72 \\
\hline & Completely disagree & 18 & 12 & 30 \\
\hline & Disagree & 12 & 18 & 30 \\
\hline \multicolumn{2}{|l|}{ Total } & 102 & 93 & $\mathrm{~N}=195$ \\
\hline \multicolumn{2}{|c|}{$\mathrm{p}$-value $=.002$} & Chi-s & istic $=26.223$ & df $=9$ \\
\hline
\end{tabular}


$H_{0}$ : Skills shortage is a factor that prevents ICT graduates from being employed (null hypothesis).

$H_{1}$ : Skills shortage is not a factor preventing ICT graduates from being employed (alternate hypothesis).

In this case the value of $X^{2}$ in Table 11 signifies 17.044 on probability, with the df at 9 and a p-value of 0.068 , which is greater than the predictable significance level of 0.05 (i.e. $\mathrm{p}>0.05$ ). The null hypothesis is therefore accepted.

$H_{0}$ : The null hypothesis that skills shortage is a factor that prevents ICT graduates from being employed is accepted.

$H_{0}$ : The type of education received is a factor that prevents ICT graduates from being employed (null hypothesis).

$H_{1}$ : The type of education received is not a factor preventing ICT graduates from being employed (alternate hypothesis).

Table 12 shows that the value of $X^{2}$ is 26.223 on probability, with the df at 9 and a p-value of 0.002 , which is less than the conventional significance level of 0.05 (i.e. $\mathrm{p}<0.05$ ). The null hypothesis is therefore rejected.

$H_{1}$ : The alternative hypothesis that the type of education received is not a factor that prevents ICT graduates from being employed is accepted.

Table 13. ICT graduates' inability to demonstrate knowledge acquired through formal education * Gender

\begin{tabular}{|c|c|c|c|}
\hline Itemised & Male & Female & Total \\
\hline ICT graduates' inability toCompletely agree & 33 & 36 & 69 \\
\hline $\begin{array}{l}\text { demonstrate knowledge } \\
\text { acquired through formal }\end{array}$ & 42 & 29 & 71 \\
\hline education $\quad$ Completely disagree & 14 & 16 & 30 \\
\hline Disagree & 13 & 12 & 25 \\
\hline Total & 102 & 93 & $\mathrm{~N}=195$ \\
\hline $\mathrm{p}$-value $=.080$ & \multicolumn{2}{|c|}{ Chi-square statistic $=15.42$} & df $=9$ \\
\hline
\end{tabular}

Tables 10, 11 and 13-15 suggest that there is no significant relationship between gender and the opinions of the respondents about the factors preventing ICT graduates from being employed. The tables show that the p-values of the respondents' views about the skills mismatch, skills shortage, ICT graduates' inability to demonstrate the knowledge acquired through formal education, no work experience upon graduation and quality of graduate as factors preventing ICT graduates from being employed were all greater than the conventional significance value of 0.05 . The exception is the $\mathrm{p}$-value shown in Table 12 which is less than the level of 0.05 (i.e. $\mathrm{p}<0.05$ ).

Overall, $H_{0}$ accepts the null hypothesis that these factors identified were preventing ICT graduates from being employed (null hypothesis), and $H_{l}$ rejects the alternative hypothesis that these factors identified were not preventing ICT graduates from being employed. Since all the p-values were greater, the null hypothesis was accepted. However, $\mathrm{H}_{l}$ accepts the alternative hypothesis that the type of education received is not a factor that prevents ICT graduates from being employed and $H_{0}$ rejects the null hypothesis that the type of education received is a factor that prevents ICT graduates from being employed given that $\mathrm{p}<=0.05$.

Table 14. No work experience upon graduation * Gender

\begin{tabular}{lllll}
\hline Itemised & Male & Female & Total \\
\hline $\begin{array}{l}\text { No work experienceCompletely agree } \\
\text { upon graduation }\end{array}$ & 30 & 25 & 55 \\
\cline { 2 - 5 } & Agree & 55 & 48 & 103 \\
\cline { 2 - 5 } & Completely disagree & 10 & 7 & 17 \\
\cline { 2 - 5 } & Disagree & 7 & 13 & 20 \\
\hline Total & 102 & 93 & $\mathbf{N}=195$ \\
\hline & p-value $=.504$ & Chi-square statistic $\mathbf{= 8 . 3 0 0}$ &
\end{tabular}


Table 15 . Quality of graduate * Gender

\begin{tabular}{lllll}
\hline Itemised & & Male & Female & Total \\
\hline Quality of graduate & Completely agree & 34 & 33 & 67 \\
\cline { 2 - 5 } & Agree & 38 & 29 & 67 \\
\cline { 2 - 5 } & Completely disagree & 20 & 26 & 46 \\
\cline { 2 - 5 } & Disagree & 10 & 5 & 15 \\
\hline \multirow{2}{*}{ Total } & 102 & 93 & $\mathrm{~N}=195$ \\
\hline & p-value $=.811$ & Chi-square statistic $\mathbf{= 8 . 9 9 3}$ & $\mathbf{d f}=\mathbf{9}$ \\
\hline
\end{tabular}

\subsection{Suggestions for Enhancing ICT Graduate Employability}

The majority of graduates were of the opinion that their respective qualifications alone would suffice to open doors to significantly high salaries and managerial positions despite their lack of experience and relevant skills required to earn them a higher salary. Regrettably, it is apparent that many ICT graduates do not possess these skills. Several reasons may contribute to why ICT graduates struggle. In an attempt to offer viable solutions to overcoming the ICT graduates' employability challenges, respondents were asked to rate the expected employability skills in accordance with the rating order required for employment.

The question was intended to determine whether the ICT graduates were able to identify which set of itemised skills were relevant for possible employment. $\mathrm{HR}=$ Highly recommended; $\mathrm{R}=$ Recommended; $\mathrm{SR}=$ Somewhat required; $\mathrm{NR}=$ Not required for employment; NS $=$ Not sure and TA $=$ Total affirmative.

Table 16. Respondents' views on expected employability skills required

\section{Cross-tabulation}

\begin{tabular}{|c|c|c|c|c|c|c|}
\hline Itemised & HR & $\mathrm{R}$ & SR & NR & NS & TA \\
\hline Work experience & $65=33.3 \%$ & $83=42.6 \%$ & $32=16.4 \%$ & $13=6.7 \%$ & $2=1 \%$ & $75.9 \%$ \\
\hline Intellectual ability and competence & $65=33.3 \%$ & $79=40.5 \%$ & $25=12.8 \%$ & $15=7.7 \%$ & $11=5.6 \%$ & $73.8 \%$ \\
\hline Workplace skills & $37=19 \%$ & $81=41.5 \%$ & $35=17.9 \%$ & $33=16.9 \%$ & $9=4.6 \%$ & $60.5 \%$ \\
\hline Hard and soft skills & $44=22.6 \%$ & $76=39 \%$ & $40=20.5 \%$ & $25=12.8 \%$ & $10=5.1 \%$ & $61.5 \%$ \\
\hline Communication skills & $62=31.8 \%$ & $59=30.3 \%$ & $47=24.1 \%$ & $20=10.3 \%$ & $7=3.6 \%$ & $62.1 \%$ \\
\hline Computer literacy skills & $73=37.4 \%$ & $63=32.3 \%$ & $48=24.6 \%$ & $3=1.5 \%$ & $8=4.1 \%$ & $69.7 \%$ \\
\hline Technical skills & $40=20.5 \%$ & $99=50.8 \%$ & $39=20 \%$ & $10=5.1 \%$ & $7=3.6 \%$ & $71.3 \%$ \\
\hline $\begin{array}{l}\text { Leadership and problem-solving } \\
\text { skills }\end{array}$ & $\mathrm{g} 19=9.7 \%$ & $77=39.5 \%$ & $76=39 \%$ & $20=10.3 \%$ & $3=1.5 \%$ & $49.2 \%$ \\
\hline $\begin{array}{l}\text { Ability to apply and execute task } \\
\text { independently }\end{array}$ & $s 45=23.1 \%$ & $77=39.5 \%$ & $45=23.1 \%$ & $22=11.3 \%$ & $6=3.1 \%$ & $62.6 \%$ \\
\hline $\begin{array}{ll}\begin{array}{l}\text { Flexibility, } \\
\text { innovativeness }\end{array} & \text { creativity }\end{array}$ & $5=33.3 \%$ & $60=30.8 \%$ & $33=16.9 \%$ & $31=15.9 \%$ & $6=3.1 \%$ & $64.1 \%$ \\
\hline
\end{tabular}

The view that ICT graduates are expected to possess certain general qualities and possible academic traits as absorbed through their educational learning process and experiences has widely been debated (Ohei \& Brink, 2019; Van der Berg \& Van Broekhuizen, 2012). The results shown above imply that certain academic qualities and skills may be advantageous to most ICT graduates as required by industry. Of the 195 participants, 148 (75.9\%) rated work experience as highly recommended skills that employers seek from any graduate for possible job consideration. This was followed by intellectual ability and competence (73.8\%). Of all the skills, ICT graduates must possess thorough intellectual ability and competence as it is one of the most vital skills required to meet workplace demands and prospects. Therefore, for a graduate to have these skills, they are required to have a generic understanding of the 
economic state, the capability to articulate assumptions, apply logical reasoning, conduct basic analysis, apply research skills, be interested and have a zeal to continue learning.

Another fundamental set of skills required by industry is technical and communication skills. A total of $71.3 \%$ of ICT graduates agreed that this set of skills was required and $69.7 \%$ agreed that computer literacy skills were required. For an ICT graduate to be able to secure IT-related employment, they must move from the theoretical to the practical. In other words, industries would prefer to hire an ICT graduate who is able to show their level of experience to solve real-time problems through practical and technical approaches. They also require the capacity to design, initiate and complete tasks individually, the talent to absorb pertinent intelligence in order to tackle hands-on workplace problems and the ability to dissect and comprehend the ever-changing business dynamics in the workplace. Flexibility, creativity and innovativeness was rated by $64.1 \%$ of respondents as required skills and the ability to apply and execute tasks independently by $62.6 \%$. Edayi (2016) and Ohei et al. (2019) affirm that these sets of academic traits and dispositions, experiences and individual characteristics distinguish graduates/students or perhaps make them more credible to secure jobs in which they can be satisfied and thrive.

Industries are often apprehensive about the qualification of graduates in relation to their capability to perform the job. This concerns the universities where the qualification was attained. This highlights the crucial role that HEIs ought to play. HEIs are one of the central stakeholders in enhancing graduate employability as their role is to identify how they can enhance the skills knowledge of their students for future job empowerment. Over the years, developing employability skills of the graduate has been an area of discourse among the policy makers who are emerging with strategy on how to produce graduates with relevant skills needed to meet the demand of the current workforce. This is the reason why Edayi (2016) believes that the approach that HEIs use to prepare students for their postgraduation lives is of the utmost importance. In the United Kingdom, HEIs have been charged with the responsibility of promoting graduate employability, which means that attention should be placed on more than just the academic skills usually represented by the subject matter or class of degree.

In the context of South Africa, several calls have been made to ensure that the higher education system in South Africa is more responsive to the social and economic needs of society to create a more direct and closer relationship between higher education and economic development. The establishment of a highly educated workforce serves as a priority for the new goal of building a knowledge-based economy in South Africa, to provide education and training to a larger number of citizens than in the past.

\section{Conclusions and Recommendations}

In light of the findings of this study, it can be concluded that most university ICT graduates are concerned about whether they will be able to secure the right employment in the labour force after completing their degree. Having these doubts has caused worry and fear in the minds of most graduates. The findings indicate how ICT graduates view employability challenges and unemployment, as well as the stress on most graduates. The challenges that come with employability have to some extent limited most ICT graduates/students in entering the South African labour market. Unemployment results in mental health risks as most unemployed graduates show a constant decrease in overall life satisfaction, general well-being and self-esteem, and symptoms of depression, especially if they are unemployed for a long period.

While high unemployment among ICT graduates as revealed in Table 1 remains the centre of attention, there is also an increasing concern that many ICT graduates are finding themselves underemployed. Joblessness and underemployment of ICT graduates suggest a bizarre and huge waste of capital and resources and an increased level of anguish among graduates. This may give rise to social segregation, intensifying disparity among graduates and a range of societal problems.

With the current unstable economic crisis and issues surrounding the labour market, the unemployment rate in SA has increased. The underlying findings of this paper concerning ICT graduate unemployability is that the economic crisis and higher education contribute to a high proportion of graduate unemployment due to an oversupply of skilled labour that is not met by an increase in demand. Additionally, a repeated contributing factor to ICT graduate unemployment was found to relate to general skills mismatch between the higher education system and the economy.

The findings reveal that the majority of graduates were of the opinion that their respective qualifications alone would suffice to open doors to significantly high salaries and managerial positions despite their lack of experience and relevant skills required to earn them a higher salary. However, many ICT graduates do not possess these skills. Several reasons may contribute to why ICT graduates struggle as presented in Tables 10-15. The contention is that the education system does not satisfactorily produce graduates for future jobs and market demands and that industries are 
hesitant to employ graduates without having to incur the costs in upskilling them.

In conclusion, certain academic qualities and skills may be advantageous to most ICT graduates as sets of skills expected by industry. Respondents regarded work experience as highly recommended and as what employers seek from any graduate for possible job consideration. Intellectual ability and competence are one of the most vital skills required to meet workplace demands and prospects. Therefore, for a graduate to have these skills, they are required to have a generic understanding of the economic state, the capability to articulate assumptions, undertake logical reasoning, conduct basic analysis, apply research skills, be interested and have a zeal to continue learning. Another fundamental set of skills required by industry is technical and communication skills.

These skills include but are not limited to computer literacy skills. An ICT graduate must move from the theoretical to the practical. In other words, industries would prefer to hire an ICT graduate who is able to show their level of experience to solve real-time problems through a practical and technical approach. They also require the capacity to design, initiate and complete tasks individually, the talent to absorb pertinent intelligence in order to tackle hands-on workplace problems and the ability to dissect and comprehend the ever-changing business dynamics in the workplace. In addition, they need the ability to apply and execute tasks independently. These sets of academic traits and dispositions, experiences and individual characteristics distinguish graduates/students or perhaps make them more credible to secure jobs in which they can be satisfied and thrive. HEIs have a vital duty in this regard, which is the obligation and responsibility to manage all stakeholders involved in a responsible and secure manner. WIL is necessary as a strategy in overcoming challenges.

\section{Acknowledgement}

At this point, it is important to mention that this paper form part of a project that is continuing, which seeks to develop a framework for addressing and enhancing ICT employability of graduates. There were two research publication that had emerged from the said project (Ohei et al., 2019 \& Ohei \& Brink, 2019). One of which targeted the prevailing issues surrounding graduates and the other focus was to develop a conceptual framework to enhance employment opportunities.

This paper being the third part of the project seeks to explore the views that graduates conceive about the employability distress, reasons for their unemployment and factor affecting their employability chances and decisively suggest way to address these challenges. What is important to note, is that this paper was based on previous study as stated. Thus, there is possibility that there may be referrals from the previous research findings and evidence published which maybe applicable in this paper.

Nonetheless, this research project is supported wholly/in part by the National Research Foundation of South Africa (Grant number: 120730).



\section{References}

Abel, J. R., \& Deitz, R. (2016). Underemployment in the early careers of college graduates following the Great Recession (No. w22654). National Bureau of Economic Research. https://doi.org/10.3386/w22654

Baldry, K. (2016). Graduate unemployment in South Africa: Social inequality reproduced. Journal of Education and Work, 29(7), 788-812. https://doi.org/10.1080/13639080.2015.1066928

Bhorat, H., Mayet, N., \& Visser, M. (2012). Student graduation, labour market destinations and employment earnings. Human Sciences Research Council Press.

Brauns, M. (2013). Employability of graduates through work-integrated learning (WIL). 18th WACE World Conference on Cooperative and Work-integrated Education (Refereed paper) Durban.

Bridgstock, R. (2009). The graduate attributes we've overlooked: Enhancing graduate employability through career management skills. Higher Education Research \& Development, 28(1), 31-44. https://doi.org/10.1080/07294360802444347 
Brink, R. (2014). An information management framework for the work-integrated learning process. Doctoral dissertation, University of Johannesburg.

Claassens, L. J. M. (2011). Human dignity in the prophetic traditions: Upholding human worth in a context of dehumanisation. Dutch Reformed Theological Journal/Nederduitse Gereformeerde Teologiese Tydskrif, 52(1-2), 34-44. https://doi.org/10.5952/52-1-4

Cloete, A. (2015). Youth unemployment in South Africa. A theological reflection through the lens of human dignity. Missionalia, 43(3), 513-525. https://doi.org/10.7832/43-3-133

Cooper, L., Orrell, J., \& Bowden, M. (2010). Work integrated learning: A guide to effective practice. Routledge. https://doi.org/10.4324/9780203854501

Creswell, J. W. (2014). A concise introduction to mixed methods research. Sage.

Du Plessis, S., \& Smit, B. (2007). South Africa's growth revival after 1994. Journal of African Economies, 16(5), 668-704. https://doi.org/10.1093/jae/ejm012

Edayi, J. (2016). Constraints to graduate employment in the city of Johannesburg, South Africa. Doctoral dissertation, University of Witwatersrand.

Farooq, S. (2011). Mismatch between education and occupation: A case study of Pakistani graduates. The Pakistan Development Review, 531-552. https://doi.org/10.30541/v50i4IIpp.531-553

Graham, L., Williams, L., \& Chisoro, C. (2019). Barriers to the labour market for unemployed graduates in South Africa. Journal of Education and Work, 32(4), 360-376. https://doi.org/10.1080/13639080.2019.1620924

Griesel, H., \& Parker, B. (2009). Graduate attributes. A baseline study on South African graduates from the perspective of employers. Pretoria: Higher Education South Africa-HESA.

Hamilton, M., Carbone, A., Gonsalvez, C., \& Jollands, M. (2015, January). Breakfast with ICT employers: What do they want to see in our graduates? (pp. 29-36). ACE.

Jackson, D. (2015). Employability skill development in work-integrated learning: Barriers and best practice. Studies in Higher Education, 40(2), 350-367. https://doi.org/10.1080/03075079.2013.842221

Jorre de St Jorre, T., \& Oliver, B. (2018). Want students to engage? Contextualise graduate learning outcomes and assess for employability. Higher Education Research \& Development, 37(1), 44-57. https://doi.org/10.1080/07294360.2017.1339183

Kraak, A. (2010). The collapse of the graduate labour market in South Africa: Evidence from recent studies. Research in Post - Compulsory Education, 15(1), 81-102. https://doi.org/10.1080/13596740903565384

Lee, M., Pitesa, M., Pillutla, M. M., \& Thau, S. (2018). Perceived entitlement causes discrimination against attractive job candidates in the domain of relatively less desirable jobs. Journal of Personality and Social Psychology, 114(3), 422. https://doi.org/10.1037/pspi0000114

Livingstone, D. W. (2018). The education-jobs gap: Underemployment or economic democracy? Routledge. https://doi.org/10.4324/9780429496622

Lowden, K., Hall, S., Elliot, D., \& Lewin, J. (2011). Employers' perceptions of the employability skills of new graduates. London: Edge Foundation.

McKenzie, S., Coldwell-Neilson, J., \& Palmer, S. (2017, January). Career aspirations and skills expectations of undergraduate IT students: Are they realistic?. In Herdsa 2017: Research and development in higher education: curriculum transformation: Proceedings of the 40th Herdsa Annual International Conference (pp. 229-240).

Mlatsheni, C. (2012). The challenges unemployment imposes on youth. Shaping the future of South Africa's youth: Rethinking post-school education and skills training (pp. 31-41).

Mncayi, N. P. (2016). The determinants of employment status of young graduates from a South African university. Doctoral dissertation, North-West University. https://doi.org/10.1177/0950422216670500

Mncayi, P., \& Dunga, S. H. (2016). Career choice and unemployment length: A study of graduates from a South African university. Industry and Higher Education, 30(6), 413-423.

Mokwena, K., \& Morojele, N. (2014). Unemployment and unfavourable social environment as contributory factors to nyaope use in three provinces of South Africa: Substance abuse. African Journal for Physical Health Education, Recreation and Dance, 20(Supplement 1), 374-384. 
National Treasury (South Africa). (2011). Confronting youth unemployment: Policy options for South Africa. Discussion Paper. National Treasury.

Ohei, K. N., \& Brink, R. (2019). Investigating the prevailing issues surrounding ICT graduate employability in South Africa: A case study of a South African university. The Independent Journal of Teaching and Learning, 14(2), 29-42.

Ohei, K. N., Brink, R., \& Abiodun, A. (2019). Information and communication technology (ICT) graduates and challenges of employability: A conceptual framework for enhancing employment opportunities in South Africa. Gender and Behaviour, 17(3), 13500-13521.

Pauw, K., Oosthuizen, M., \& Van der Westhuizen, C. (2008). Graduate unemployment in the face of skills shortages: A labour market paradox 1. South African Journal of Economics, 76(1), 45-57. https://doi.org/10.1111/j.1813-6982.2008.00152.x

Pramudia, J. R., Ardiwinata, J. S., Sudiapermana, E., \& Hilmi, M. I. (2019, July). The Soft Skill Training to Improve the Readiness of Alumni in Entering the Working World. In 2nd International Conference on Educational Sciences (ICES 2018). Atlantis Press. https://doi.org/10.2991/ices-18.2019.26

Rogan, M., \& Reynolds, J. (2016). Schooling inequality, higher education and the labour market: Evidence from a graduate tracer study in the Eastern Cape, South Africa. Development Southern Africa, 33(3), 343-360. https://doi.org/10.1080/0376835X.2016.1153454

Rosenberg, S., Heimler, R., \& Morote, E. S. (2012). Basic employability skills: A triangular design approach. Education Training, 54(1), 7-20. https://doi.org/10.1108/00400911211198869

Saad, M. S. M., \& Majid, I. A. (2014). Employers' perceptions of important employability skills required from Malaysian engineering and information and communication technology (ICT) graduates. Global Journal of Engineering Education, 16(3), 110-115.

Spaull, N. (2013). South Africa's education crisis: The quality of education in South Africa 1994-2011. Johannesburg: Centre for Development and Enterprise, 1-65.

Statistics South Africa. (2018). Quarterly labour force survey. Statistics South Africa.

Stats, S. A. (2019). Quarterly labour force survey: Quarter 3 2019, Statistical Release P0211. Statistics South Africa, Pretoria. Retrieved from http://www.statssa.gov.za/publications

Taljaard, J., \& Van der Walt, F. (2018). Employment and inequality challenges facing South African agriculture in a minimum wage dispensation. African Journal of Public Affairs, 10(4), 212-229.

Tripathy, M. (2018). Building quality teamwork to achieve excellence in business organizations. International Research Journal of Management, IT and Social Sciences, 5(3), 1-7. https://doi.org/10.21744/irjmis.v5i3.662

Van Broekhuizen, H. (2016). Graduate unemployment and higher education institutions in South Africa. Bureau for Economic Research and Stellenbosch Economic Working Paper 08, 16.

Van der Berg, S., \& Van Broekhuizen, H. (2012). Graduate unemployment in South Africa: A much exaggerated problem. Centre for Development and Enterprise, Stellenbosch University.

\section{Copyrights}

Copyright for this article is retained by the author(s), with first publication rights granted to the journal.

This is an open-access article distributed under the terms and conditions of the Creative Commons Attribution license (http://creativecommons.org/licenses/by/4.0/). 